\title{
衛星データおよび砂粒子の熱ルミネッセンスの分析に基づく スリランカ西海岸における沿岸漂砂環境の解明
}

\author{
Investigation of Nearshore Sedimentary Characteristics along the West Coast of Sri Lanka \\ Based on the Analysis of Satellite Images and Feldspar Thermoluminescence
}

\author{
田島芳満 $^{1} \cdot$ 望月翔平 $^{2} \cdot$ 舟竹祥太郎 $^{2} \cdot$ Wickramaarachchi BANDULA $^{3}$ \\ Samalakoon $\mathrm{LAL}^{4} \cdot$ 祖父江真 ${ }^{5}$ ・佐藤懭司 ${ }^{6}$
Yoshimitsu TAJIMA, Shohei MOCHIZUKI, Shotaro FUNATAKE, Wickramaarachchi BANDULA Samalakoon LAL, Shinichi SOBUE and Shinji SATO

\begin{abstract}
This paper investigates sedimentary characteristics along the west coast of Sri Lanka based on satellite images, feldspar thermoluminescence (TL) and numerical shoreline model. Analysis of aerial photograph and satellite images first revealed significant sedimentation around Kalpitiya, the northern part of the west coast, and severe erosion in the central and southern part of the coast. Monotonous northward decrease of TL indicated the dominant northward sediment transports and also a lack of sediment supply in the central and northern part of the coast. Analysis of ALOSPALSAR data finally captured the more detailed shoreline dynamics around Kalpitiya with frequencies of several months. Based on all these findings, shoreline model was finally applied for predictions of the alongshore sediment budgets.
\end{abstract}

\section{1.はじめに}

漂砂移動が卓越的な沿岸域の開発では，局所的な漂砂 環境の変化に加え, より広域的・長期的な沿岸漂砂量の 収支を勘案した環境影響評価が本質的に重要である。た とえばスリランカ北西部沿岸域では, 内戦の終焉ととも に開発熱が高まりをみせているものの, 年スケールで激 しく変動する沿岸域地形の変形特性は明らかにされてい ない.とりわけ西海岸北部の沿岸域地形は, 南西モンス ーンの来襲に伴う北向きの沿岸漂砂によって形成された と考えられているが（たとえばSwan，1983），南部では 海岸侵食が進行しており，これに伴う長期的な北向き沿 岸漂砂の減少は北西部沿岸域の海浜地形に甚大な影響を 及ぼすことが推測される.

本研究では，この様に広域的かつ長期的に変容するス リランカ西海岸における沿岸漂砂環境を俯瞰的に監視す ることが可能な衛星デー夕に着目し，これに砂粒子の熱 ルミネッセンス特性の分析や汀線変化モデルを組み合わ せることによって, その特性の解明を試みる.さらにこ れらの分析を通じて, 様々な地点に適用可能な汎用性の 高いモニタリングシステムの構築に向けた知見を得るこ

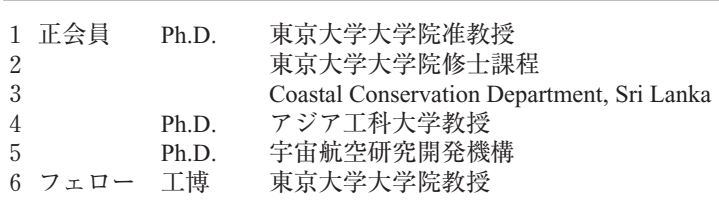

とも本研究の大きな目的のひとつとして位置づける.

\section{2. 西海岸全域におけるマクロな沿岸漂砂環境の 推定}

\section{（1）海岸線の比較}

図-1にスリランカ海岸線および主要な河川の位置，お よび後述するThermoluminescence（TL值）の沿岸方向分 布を示す。さらに，図-2〜4には，航空写真や衛星画像 に基づくColombo 港北側，Chilaw，さらにKalpitiya周辺 における汀線位置の時間変化を比較する。ここで 2000 年

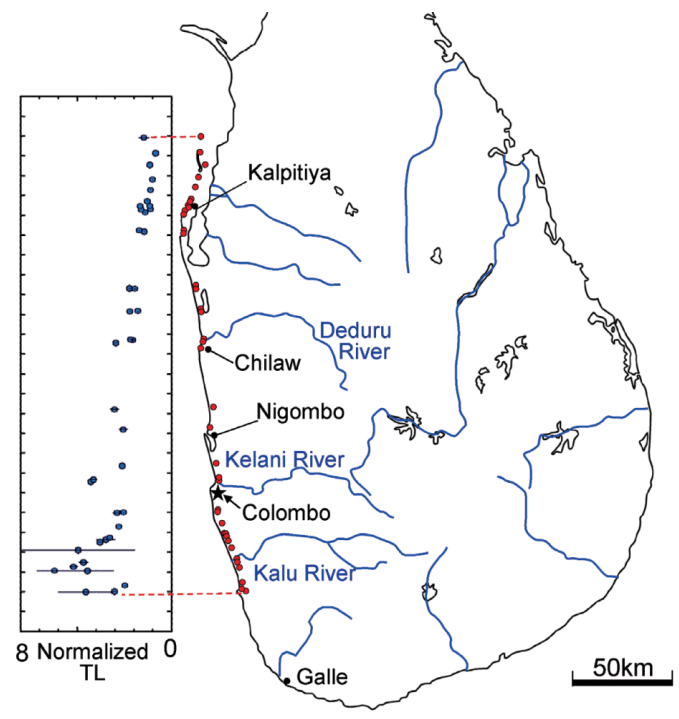

図-1 Sri Lanka西海岸および規準化したTL值の沿岸方向分布 


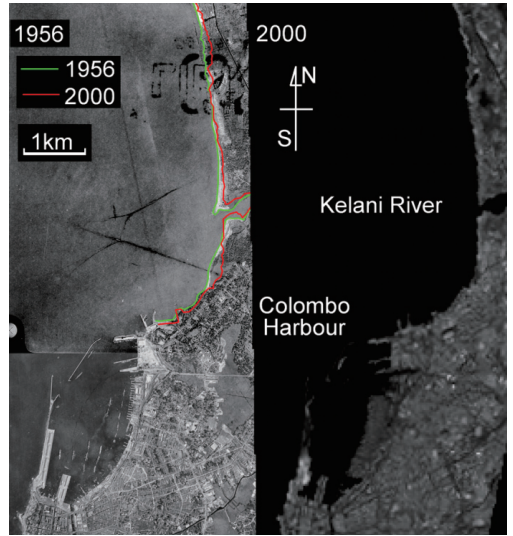

図-2 Colombo港北側での汀線位置の変化

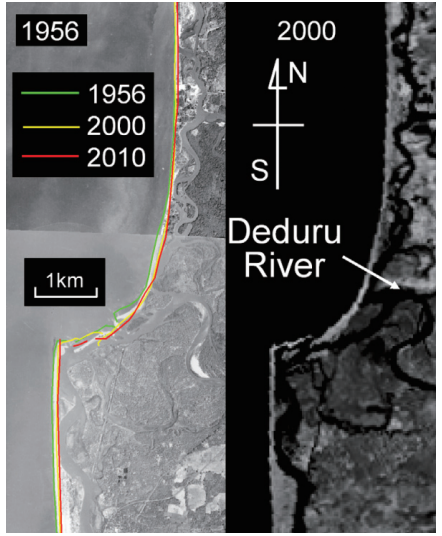

図-3 Chilawにおける汀線位置の変化
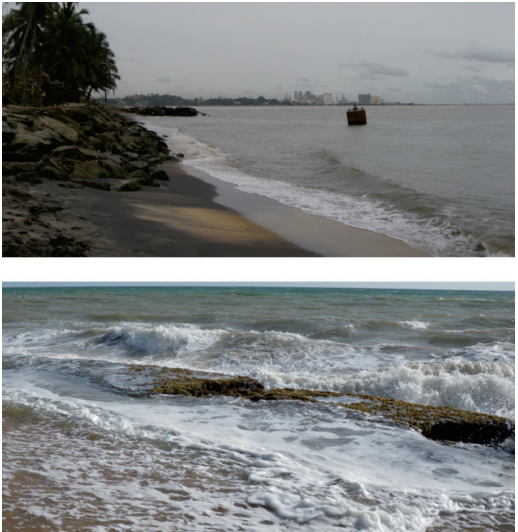

図-5 Colombo周辺の護岸・突堤 (上), および Chilaw 以南で発達する砂質岩 (下)

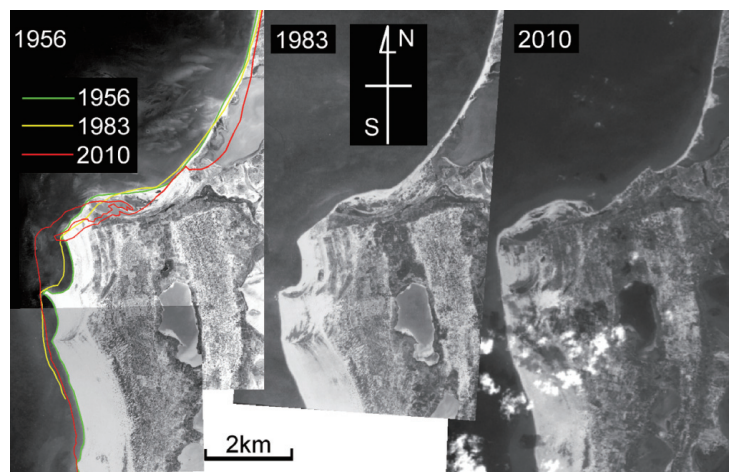

図-4 Kalpitiyaにおける汀線位置の変化

の衛星画像にはLANDSATを用い，Kalpitiyaにおける 2010年の衛星画像にはALOS PRISM画像を用いた。また 図-5には, 護岸や突堤が並ぶColombo 周辺の海岸線, Chilaw 以南で多く見られた海岸線を覆う砂質岩の写真を それぞれ示した。

図に見られるように, Colombo 掞よびChilawでは1956 年の航空写真から 2000 年の LANDSAT 画像にかけて汀線 が大きく後退している様子が分かる，スリランカの Coastal Conservation Department（CCD）によれば，西海 岸南部で深刻な侵食域は北に拡大しており, その北端は 現時点で図-3に示したChilaw北側に達している．衛星画 像の比較においても, 顕著な汀線後退が見られたのは Chilawまでであり，CCDから得た情報と一致している. また特にDeduru川河口部北側では 2000 年から 2010 年に かけても汀線位置が後退しており, 現在も侵食域が徐々 に搪大していることが推測される。またChilaw南側の直 線的な海岸線では汀線変化量が小さいが, これは海岸線 が図-5に示した砂質岩に覆われているためであると考え られる。

次に図-4を見ると, 図の南側の南北に伸びた海岸線で は，1956年から2010年にかけて汀線位置が大きく前進し

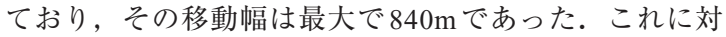
し, 図の北側領域では, 汀線が東向きにほほ直角に曲が った地点周辺で顕著に前進し, その北側の砂州では大き く後退している. Kalpitiya周辺での汀線変化については, 次節でさらに詳細な分析を行う.

以上より, スリランカ西海岸ではChilaw 以南で侵食, Kalpitiya で堆積傾向が見られ, 南西モンスーンに伴う北 向き沿岸漂砂が卓越的であること, また南側の侵食域が 拡大していることから, 南側からの土砂供給が枯渴して きていることなどが推察される.

\section{（2）熱ルミネッセンスの沿岸方向分布}

汀線近傍で採取した砂粒子の熱ルミネッセンス（TL） の計測結果に基づき，沿岸方向への砂粒子の移動特性の 推定を試みる。岸本ら（2008）やKeizarsら（2008）によ れば，陸域から供給された土砂の TL 值は相対的に大き く, 漂砂が海岸線に沿って沿岸方向に輸送される際に露 光することによって TL 值が減少する. 本研究において も岸本ら（2008）にならい, 海岸線でのサンプル砂は, 満潮時汀線位置を目安に, 砂面表層から約 $30 \mathrm{~cm}$ 下の堆 積層から露光させることなく採取した。採取した砂の前 処理の方法およびTL信号の計測方法については, 岸本 ら（2008）の手法をそのまま用いた。

以上の操作により得られた TL信号強度を, 同一粒子 に $\beta$ 線を 60 秒間照射した後に計測した TL值で除して正規 化し，その沿岸方向分布を比較した（図-1）. 図に見られ るように, TL值は北に向かってほほ単調に減少している ことが分かる. 特にColombo 以南に位置する Kalu川河口 周辺では高いTL值が計測されており, 現在でも陸域か らの土砂供給があることが推察されるものの, TL值は Colombo 港を境に急激に減少しており, Colombo港が沿 岸漂砂をほぼ遮断していることも分かる。さらに Colomboの北側に着目すると, Kelani川の近傍でTL值の 上昇が見られるものの, その值は Kalu川河口部に比べて 
相対的に小さく, Kelani 川からの土砂供給量が相対的に 小さいことを示唆している，さらに，河口部の両岸では TL值が急激に低下していることから，Kelani川から流出 した土砂は多くが河口部にとどまり，周辺沿岸域への土 砂供給源にはなっていないことが推測される。CCDによ れば，Kelani川河口部では過去に河床材料の採取が頻繁 に行われ，河口部での水深は $10 \mathrm{~m}$ を超える地点もあるな ど，TL值の計測結果から推定される漂砂環境と符合して いる.

さらに北側に目を移すと，Chilawに㧍けるDeduru川河 口部では，その周辺でTL值は変化していない，Larsonら （2009）によれば，Deduru川河口域では頻繁に河口閉塞 が起こっており，また，南部に比べると流域の標高が低 いことから，土砂を輸送するだけの流量がないことが推 察され, 本研究で得られたTL計測結果と符合する.

以上の考察より，TL計測結果からも北向きの沿岸漂砂 が卓越すること，漂砂の多くはColombo 周辺で遮断され ていること, Colombo 以北では大きな土砂供給源がない ことなどが分かり，その結果，侵食域は今後も北向きに 拡大し, 長期的にはKalpitiya周辺にも深刻な影響を及ほ すことなどが推察できる.

\section{PALSAR画像に基づく海岸線位置の抽出}

航空写真や衛星画像の比較および砂粒子の熱ルミネッ センスの沿岸方向分布の分析を通じて，スリランカ西海 岸に打けるマクロな漂砂特性を把握した。ここでは，減 少を続ける北向沿岸漂砂の環境下において，Kalpitiyaの 沿岸域地形がどのように変容しているのか, PALSAR画 像に基づくより詳細な分析を行う。

衛星デー夕に基づく沿岸域監視で，最も重要となる問 題のひとつはデー夕の時空間解像度である．たとえば前 節で用いたLANDSATやPRISMなどの可視光画像では， 地表面の様子を高解像度で記録することができるもの の, 雲や日照条件の制約により定期的監視ができない. そのため，季節変動や潮汐などの短期的な変化による影 響と，長期的なトレンドを分離することは困難である。 そこで本研究ではALOS・PALSAR画像に基づく汀線位 置の抽出を試みる。PALSARは衛星から照射したマイク 口波の反射を受信・記録する合成開ロレーダーであり， 日照条件や雲の被覆率による影響を受けることなく，定 期的な定点観測が可能である.

\section{（1）汀線位置の抽出方法}

PALSARにより得られるSAR画像は，地表におけるマ イクロ波の散乱強度の平面分布を示したものである。散 乱強度は地表の粗度や土壤水分による影響を受けること が知られ，一般には地表面の凹凸が大きい陸域からの散 乱強度の方が水面からのそれよりも大きくなる．本研究

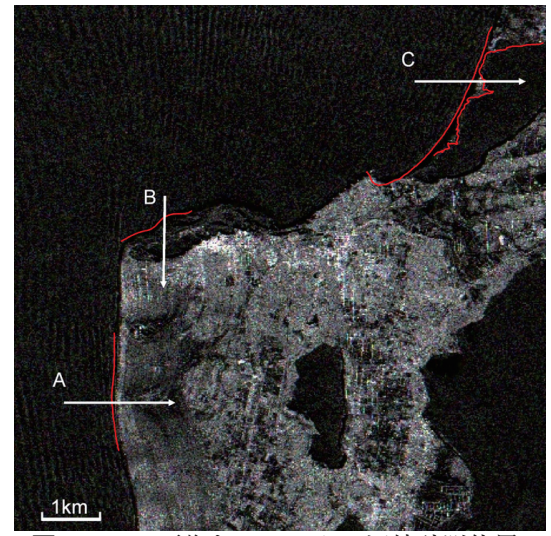

図-6 SAR画像とGPSによる汀線計測位置

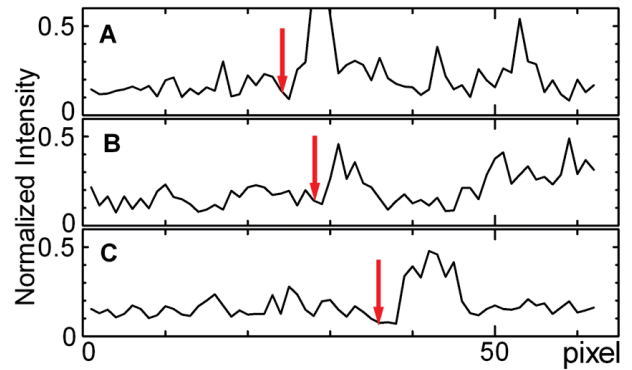

図-7 測線 $\mathrm{A} \sim \mathrm{C}$ 上の散乱強度 (正規化) と汀線位置 (矢印)

ではまず，対象とするKalpitiya周辺における汀線境界が SAR画像の中でどのように判別できるのかを確認するた め，GPSを用いて計測した汀線位置と同じ時期に取得し たSAR画像とを比較した（図-6）。

図に見られるように，計測した汀線位置（赤線）は， 確かに強い散乱強度（明るい）分布を示した陸域と, 弱 い（暗い）分布を示す海域の間に位置するが，ここで比 較した多くの地点では，赤線よりも陸側により散乱強度 の小さな領域があることが分かった．図-6に示した代表 的な測線に㧍ける正規化した散乱強度の分布（図-7）を みるとその傾向はより明確であり，砂浜では表面の凹凸 が䂗波带よりも小さく，結果として相対的に小さな散乱 強度分布を示していたことが推察される。

以上より，本研究では散乱強度の大きい陸域の周囲を 縁どるように散乱強度の小さい領域が存在する場合に は，その外縁を汀線境界として抽出することとした。本 研究では汀線境界上に赤線を描き，赤線の画素座標を自 動抽出して汀線位置情報を出力した.

次に，2007年1月 14 日に取得したSAR 画像を基準画像 とし，その中から基準とする地点を複数選定して，それ らの地点の緯度経度情報から画像の中心を原点とする平 面直角座標系上での座標を算出した。その他の日時に取 得したSAR 画像については，基準点の画素座標と算出し た平面直角座標に基づき，田島ら（2008）と同様の座標 
変換手法を用いて両座標間の変換式を求めた。最後に各 画像で抽出した汀線位置の画素座標から, 平面直角座標 上での座標位置を算出した，以上の処理を施すことによ り，異なるSAR画像間の相対誤差を最小にとどめること ができると考えられる．本研究では，2007年から 2010年 までを対象に合計 12 枚のSAR画像を用いたが，座標変換 時における各座標の推定誤差は最大でも 1 画素未満であ った。汀線位置の判定にも同程度の誤差が含まれると考 えられるが，それでも各画像間の相対的な汀線位置の抽 出誤差は $1 \sim 2$ 画素以内（10～20m 程度）であると考元 られる。

(2) Kalpitiya 周辺における汀線変化

以上の操作に基づき抽出した汀線デー夕の一部を 2007 年1月14に取得したSAR画像上にプロットしたものを図-8 に，同日の汀線位置を基準とした汀線位置の変化量（基 準汀線上の任意の点から伸ばした法線と他の日時の汀線 との交点までの距離）の沿岸方向分布を図-9に示す。こ こで横軸の沿岸方向距離は, 基準汀線に沿った距離であ り, 図-8にもその位置を示している。また図-8には狭領 域として, 特に汀線位置の変動が顕著だった $20 \mathrm{~km}$ 地点 近傍の汀線位置の比較も示した。さらに, 図-10には,
代表的な沿岸方向区間で $100 \mathrm{~m}$ 間隔で選定した汀線位置 における，汀線変化量の経時変化を示す。

図-8より，大きな汀線変化は背後にも海域が広がる細 長く標高の低い砂州上 (20 km 地点) で卓越的であり, 沿 岸漂砂の収支だけではなく, 高波浪時の越波による岸向 きの漂砂移動が汀線位置の変動に大きく寄与しているこ とが推定される.また，図-9に扔いても $20 \mathrm{~km}$ 地点周辺 における汀線後退は顕著であるが，一方で沿岸漂砂の “上流側”に位置する $15 \mathrm{~km}$ 地点では汀線の前進が顕著で ある.この地点は, かつての海岸線の沖側に大きく砂嘴 が張り出した地点であり, 分析対象期間中にも相当量の 堆砂があったものと考えられる.

次に図-10に着目すると，対象とした 2007 年から 2010 年にかけては, $15 \mathrm{~km}$ 地点で汀線が前進， $20 \mathrm{~km}$ 地点では 後退するトレンドが読み取れるが，他の地点においては 汀線位置は短期的な若干の変動はあるものの, 相対的に 安定であったと言える. また汀線変化が顕著な $20 \mathrm{~km}$ 地 点や $15 \mathrm{~km}$ 地点では, 季節的な傾向も読み取れ, たとえ ば北東モンスーンが卓越的で西海岸では比較的波浪が静 穏な冬季にかけて, $20 \mathrm{~km}$ 地点では汀線の後退が見られ, 逆に南西モンスーンが卓越する夏秋を経た後, $20 \mathrm{~km}$ 地点
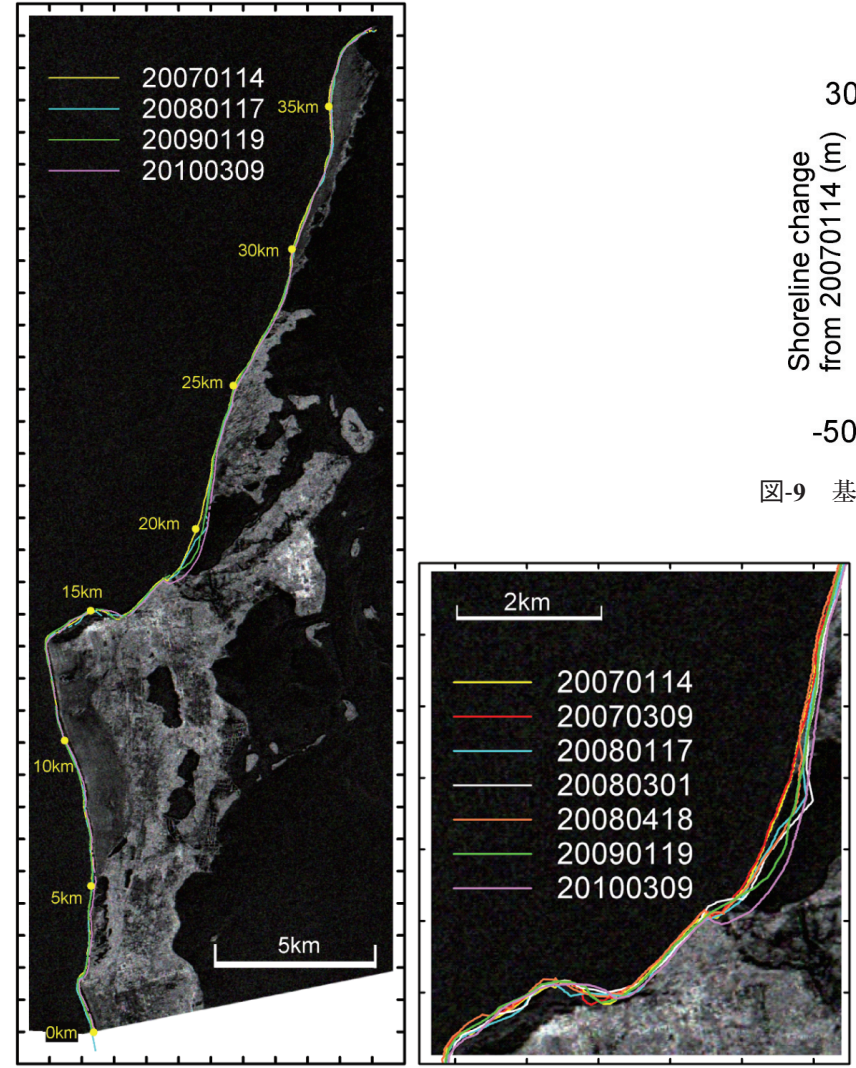

図-8 SAR画像から抽出した汀線位置の比較（広領域 (左), 狭領域 (右)

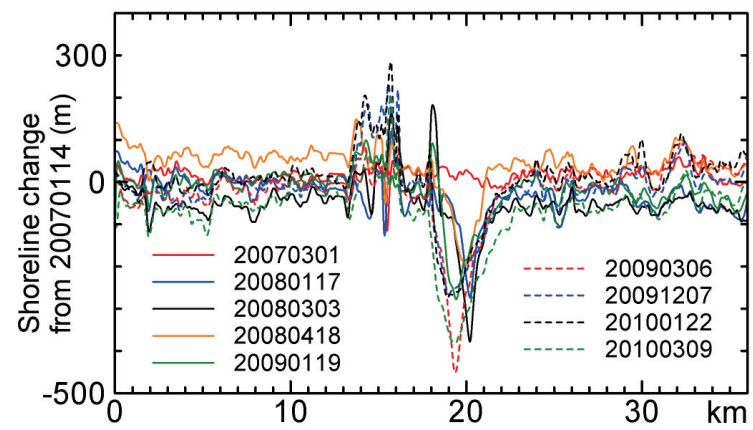

図-9 基準汀線 (2007年1月14日) からの汀線変化量の沿岸方向分布

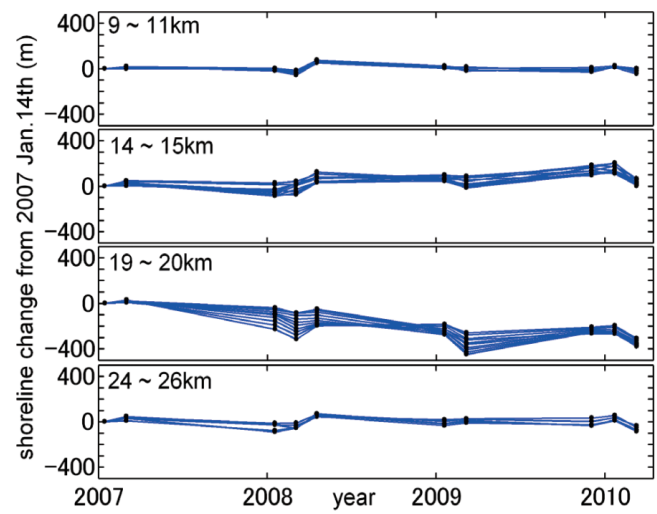

図-10 各地点における基準汀線 (2007年1月14日)から の汀線変化量の経時変化 


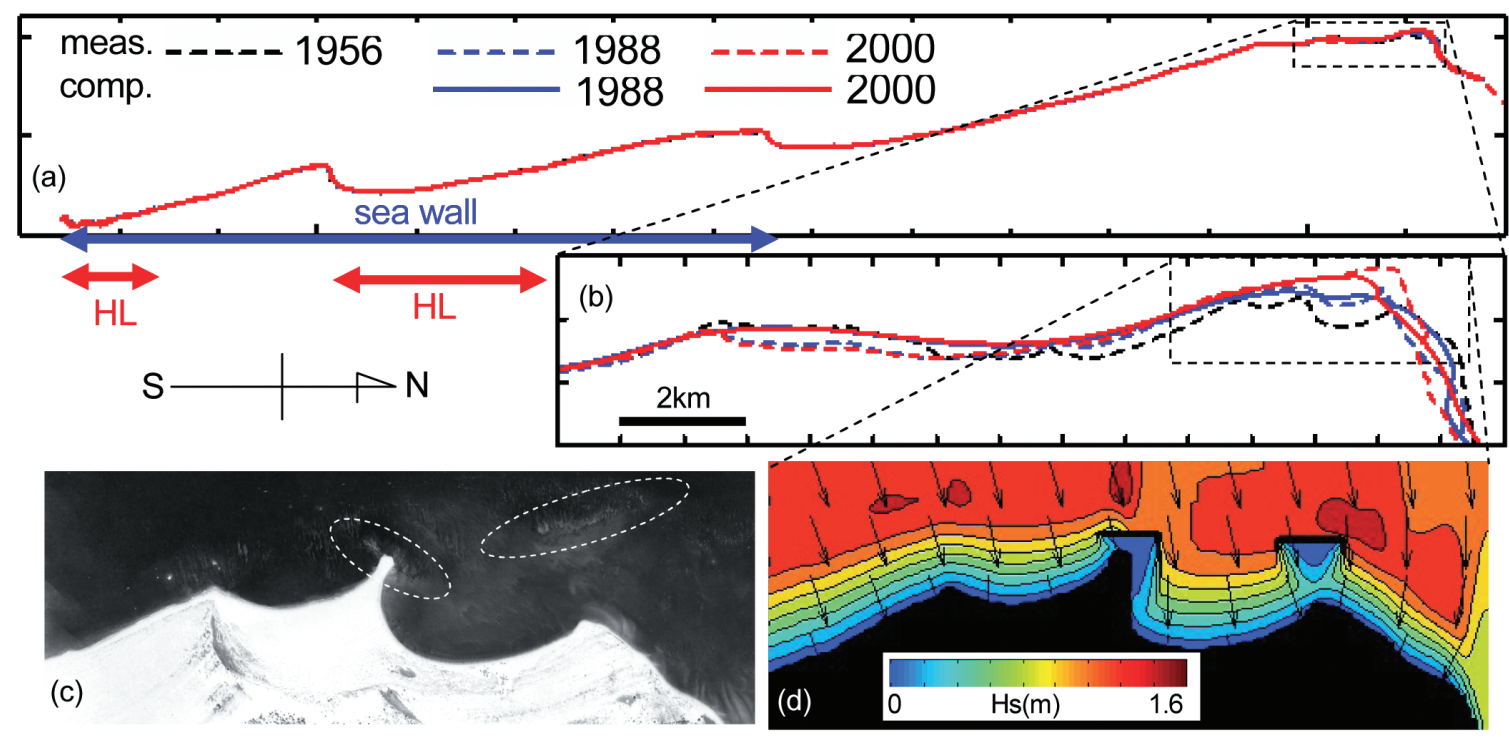

図-11（a）1-lineモデルの計算範囲と結果，（b）切り出して拡大した1-lineモデル計算結果の一部，（c）Kalpitiyaに拈ける航空写真 (破線囲み内にさんご礁が見える), および（d）航空写真と同じ範囲で切り出した波浪場計算結果の一例.

の汀線位置は前進する傾向が見られる。この様にSAR画 像を用いることにより，季節的な汀線変動特性まで考察 することが可能になると考えられるが，より詳細な考察 を行うためには更なるデー夕の蓄積が必要である.

\section{4. 汀線変化モデルによる分析}

以上の分析より，スリランカ西海岸では卓越的な北向 漂砂が減少傾向にあるが, Kalpitiya周辺まではその影響 が顕著には現れていないことが推察できた。ここでは汀 線変化モデルによる過去 50 年の再現計算を試み，過去お よび将来の沿岸漂砂量の収支について検討を行う。

図-11に汀線変化モデルによる計算結果および, Kalpitiya周辺に扔ける航空写真と波浪場の計算結果の一 例を示す．汀線変化モデルは小笹・Brampton（1979）の モデルを用い，衛星画像から抽出した護岸やヘッドラン ド（HL）の配置（図の矢印の範囲）を忠実に再現した. 漂砂量係数は $K_{I}=0.3$ とし, 移動高を $10 \mathrm{~m}$ とした. 砕波点 での波高および波向は回折を考慮したエネルギー平衡方 程式で算定し，Kalpitiyaで見られた大規模な堆積域を再 現するため, 航空写真で見られた汀線沖側のさんご礁を 離岸堤として再現した。その結果，モデルは実際の汀線 変化を妥当に再現することができ，このときの沿岸漂砂 量は, Chilawの北側で約 50 万 $\mathrm{m}^{3} /$ 年であることが分かっ た。さらに同じ条件で将来予測解析を行ったところ，護 岸部前面における水深が増大し, 結果として今後 50 年程 度でKalpitiya南部における北向沿岸漂砂量が減少傾向を 示し始めるという結果を得た。

\section{5. おわりに}

衛星デー夕，砂粒子の熱ルミネッセンス，および汀線 変化モデルを用いて，広域的・長期的にダイナミックに 変容するスリランカ西海岸に抒ける沿岸漂砂環境の実態 把握を試みた。これらの手法を組み合わせることにより， 特に土砂の供給源を含む広域的な土砂収支について，有 用な知見を得ることができた。尚，本研究はAPRSAF （アジア太平洋宇宙機関会議）の国際協力の枠組の下で 実施されたものであり，関係各位に謝意を表します。

参 考 文 献

小笹博昭・A.H. Brampton（1979）：護岸のある海浜の汀線変 化数值計算, 港湾技術研究所報告, 第 18 巻, 第 4 号, pp. $77-103$.

岸本 瞬 - 劉 海江 - 高川智博 - 白井正明 - 佐藤懭司 （2008）：長石の熱ルミネッセンス特性に基づく流砂系の 土砂移動の分析, 海岸工学論文集, 第 55 巻, pp.686-690.

田島芳満 - 高川智博 - 浅野泰史 - 佐藤㯖司 - 武若 聡 （2008）：特性の異なる二つの台風による天竜川河口砂州 の大規模地形変形, 海岸工学論文集, 第 55 卷, pp.646650.

Keizars, K.Z., B.M. Forrest and W.J. Rink (2008) : Natural residual Thermoluminescence as a method of analysis of sand transport along the coast of the St. Joseph Peninsula, Florida, J. of Coast. Res., 24, pp.500-507.

Larson, M., N. Wikramanayake and H. Hanson (2009) : Seasonal closure of Chilaw inlet in Sri Lanka: Physical processes and mathematical modeling, Coast. Dyn., CD-ROM, paper No.97.

Swan, B. (1983): Coastal Geomorphology of Sri Lanka, National Museums of Sri Lanka, 182p. 